\title{
Insurance-Growth Nexus: Aggregation and Disaggregation
}

\author{
Umera ZULFIQAR ${ }^{1}$, Sajid MOHY-UL-DIN² , Ayman ABU-RUMMAN ${ }^{3}$, Ata E.M. AL-SHRAÁH ${ }^{4}$, Israr AHMED ${ }^{5}$ \\ Received: September 10, 2020 Revised: November 08, 2020 Accepted: November 16, 2020
}

\begin{abstract}
The aim of this article is to investigate the relationship between insurance and economic growth at aggregate and disaggregate level for the period 1982-2018. Very few studies have been carried out in this field, with contradictory results and using an aggregate data while, according to different authors, an aggregate data might provide spurious results. The author used Ordinary Least Squares Regressions (OLS) and Granger Causality tests to explore the strength and direction of the relationship between insurance and economic growth at an aggregate level. To check the relationship at disaggregate level life insurance, marine insurance, and property insurance are regressed on trade openness and investment, respectively. Non-life insurance at an aggregate level plays a positive and significant role in promoting economic growth, but life insurance has an insignificant impact on the Pakistan economy. On the other hand, non-life insurances at a disaggregated level such as marine insurance negatively affect a vital part of economic growth, i.e., trade. At the same time, property insurance has a significant and positive role in boosting investment. Life, marine, and property insurance Granger cause economic growth, trade, and investment in a single direction. Nevertheless, is a bi-directional relationship between economic growth and non-life insurance.
\end{abstract}

Keywords: Life-Insurance, Non-Life Insurance, Economic Growth, Trade-Openness

JEL classification Code: G22, O4, F4, E22

\section{Introduction}

Ahmed and Ahsan (2011) argued that the share of the services sector in the overall economy for the underdeveloped/low-income countries is $47 \%, 53 \%$ for the middle/developing, and $73 \%$ for the developed high-income countries. Similarly, according to the State Bank (SBP)

${ }^{1}$ First Author. University of Huddersfield, UK.

Email: umera.subhan@gmail.com

${ }^{2}$ Corresponding Author. Assistant Professor, University of Lahore, Pakistan [Postal Address: 1- Km Raiwind Rd, Sultan Town,

Lahore, Punjab, Pakistan] Email: sajidmohyuldingsk@yahoo.com

${ }^{3}$ Associate Professor, Business School, Al-Ahliyya Amman

University, Jordan. Email: a.aburumman@ammanu.edu.jo

${ }^{4}$ Associate Professor, The Hashemite University, Jordan.

Email: Temp3@staff.hu.edu.jo

${ }^{5}$ School of Business Management, Universiti Utara Malaysia, Malaysia.

Email: chaudhryisrar@gmail.com

(c) Copyright: The Author(s)

This is an Open Access article distributed under the terms of the Creative Commons Attribution Non-Commercial License (https://creativecommons.org/licenses/by-nc/4.0/) which permits unrestricted non-commercial use, distribution, and reproduction in any medium, provided the original work is properly cited. of Pakistan (2008), the services sector contributes a 54\% share of the overall economic development of Pakistan as compared to the manufacturing sector share that is about $46 \%$. The share of insurance was about $4 \%$ in 2007 as compared to a share of $2.6 \%$ in 2001. Moreover, SBP (2003) concluded that insurance industry in Pakistan is still unable to produce sufficient demand. In addition to this, several factors affect the demand of insurance in any country such as interest rates, inflation, economic environment, political stability, culture, religion, insurance premium rates, and individual preferences for the security are some of them.

Insurance can be classified into three categories, namely, life, non-life, and reinsurance. Pakistan, being an emerging economy, has great potential to boost investment and international trade. Insurance can provide better risk management to individuals and corporations with united resources available to cope with uncertain situations. Din et al. (2013) highlighted that at the time of independence, 77 insurance companies were operating under the Insurance Act 1938. Later, in 2000, the Insurance Act of 1938 was replaced with the new Insurance Ordinance 2000 and the governing power shifted from the Ministry 
of Finance to the Security and Exchange Commission of Pakistan (SECP) under the new ordinance. SECP doubled the paid-up capital requirements for the non-life insurance sector (i.e., from Rs40 to 80 million), while increasing it one and a half times for life insurance (i.e., from Rs100 to 150 million). As a result, according to the Insurance Association of Pakistan (2014), currently 35 insurance companies are operating in Pakistan, out of which 27 are offering non-life insurance, seven life insurance, and one is a reinsurance company.

Andersson et al. (2010) emphasized that economic growth of a country largely depends on a strong financial system. Many researchers explored the role of financial institutions like banks and stock markets on economic growth but the insurance sector remained ignored until the 1990s (Dash et al., 2018; Din, Angappan, \& Baker, 2017; Din, Regupathi, Abu-Bakar, Lim, \& Ahmed, 2020; Pham \& Doan, 2020; Ratnawati, 2020; Ruiz, 2018). Insurance performs three main functions, namely, risk transfer, indemnification, and intermediation. The oldest form of insurance was marine/sea insurance, which facilitates cross-country trade that subsequently improves economic growth (Njegomir \& Stojić, 2010). However, Din et al. (2013) found that non-life insurance at an aggregate level plays a very significant role in economic growth in the long run for Pakistan, but interestingly they found that at the disaggregate level marine insurance negatively affects economic growth (trade). One of the main setbacks of their study was that they only focused on the non-life insurance aspect of insurance that transfers and indemnifies the risk while the role of financial intermediation is logically and specifically associated with life insurance, which they did not incorporate into their study.

This study will investigate the long-term relationship between insurance at an aggregate level and economic growth. Moreover, as highlighted by Kugler and Ofoghi (2005), a relationship may exist at an aggregate level but not concentrate individual components of insurance. Therefore, this study will also investigate the relationship between components of insurance (life and non-life) and economic growth. In addition to this, the relationship between non-life insurance's components (marine, fire, etc.) will also be investigated with the components of economic growth (trade and investment). To the best of the author's knowledge, not a single paper has tested this type of relationship at a disaggregate level, i.e., impact of marine insurance on trade and the impact of fire/property insurance on investment by Din et al (2013) in a single study. Although research has considered the relationship between insurance at a disaggregate level with economic growth there may be a problem of using aggregation for economic growth.

\section{Literature Review}

There is no consensus on the definition of risk and every field, i.e., economy, psychology, and statisticians used different definitions to express risk. However, every definition more or less revolves around a common point uncertainty. Therefore, we can say when one is unable to objectively conclude any specific event, but assign probabilities through mental shortcuts (subjectivity) (Rejda, 2013). In addition, he classified the risk into fundamental, particular, pure, and speculative risk. Similarly, Wilier (1951) said that risk is uncertainty about the future that can be estimated with the help of all the attainable knowledge of the proceeding conditions.

Rejda (2013) said pure risk contains chances of loss only while there is the possibility of profit and loss as well in case of speculative risk. Fundamental or systematic risk affects all the entities operating within a system, however, the severity of effects differ from organization or organization. On the other hand, risk faced by a particular organization is term as particular risk or unsystematic risk. Barro and Martin (2000) stated that every economic activity contains a certain level of risk and this place an additional expense on companies to tackle with the uncertain business environment. Rejda (2013), however, said that risk could be managed by implying one of these methods:

1) Avoid taking a risk at all.

2) Controlling the frequency or severity of loss either by loss prevention or by loss reduction

3) Retaining all or part of the risk either intentionally (due to the high cost of insurance or unavailability of insurance) or unintentionally.

4) Transferring the risk to non-insurance companies by contracts, future hedging, or business incorporations.

5) By purchasing the insurance

Gupta and Aggarwal (2014) defined insurance as the transfer of risk from insurer to insured for a payment known as a premium. Furthermore, the insurance industry can be classified into two board categories i.e. life and non-life. Life insurance protects individuals from the income-related problems arising from premature death or retirement (annuities, manage pension plans, etc.), non-life insurance protects policyholders from losses other than life. In addition, they further classify life insurance companies into four classes, i.e., ordinary (term, whole life, endowment, variable, and universal), group, industrial, and credit life. Moreover, Saunders and Cornett (2008) highlighted that the principal problem faced by almost all life and non-life insurance companies is an adverse selection (insurance policies are purchased only when the chance of loss is high).

Chang, Lee, and Chang (2013) stated that the average rate of growth in the insurance industry (i.e., 10\%) was much higher than the rate of economic growth globally. 
Furthermore, they concluded that the relationship between insurance and growth is not stable for any country, results showing that the insurance industry, life, and non-life insurance, promoted economic growth in the UK, Netherlands, Japan, France, and Switzerland, while in Canada only life insurance played a significant role. Similarly, life insurance significantly affects economic growth in Italy. These results are consistent with the study of Ward and Zurburegg (2000).

Many contemporary scholars have highlighted the importance of financial institutions in developing the economic growth of a country (Catalan, Impavido, \& Musalem, 2000; Levine, 1992; Nguyen, 2020). Saunders and Cornett (2008) argued that financial institutions could be categorized as commercial banks, investment banks, savings banks, or as insurance companies. However, the majority of them emphasize the role of the stock market or banks as the key financial institutions that may promote economic growth. Ward and Zurbruegg (2000) stated that insurance, not only transfers and indemnifies risk, but also plays the role of financial intermediation. However, the role of other financial institutions such as if insurance has been little explored (Hana et al., 2010; Haiss \& Sumegi, 2008). The role of insurance is increasing over time due to the increasing importance of insurance in the overall financial system of a country. Nevertheless, the literature on the role of the insurance sector as a promoter of economic growth is scarce compared to that considering other financial institutions. Insurance is vital for secure banking in the short run. Similarly, life insurance companies are a major player in the stock market. The financial system normally performs the following functions; hedging; pooling of risk; efficient allocation of scarce resources; mobilizing savings; trade and commerce; loss mitigation; and better pricing of risk (Levine, 1997; Skipper, 2006; Kugler \& Ofoghi, 2005). In addition to this, insurance companies promote trade, commerce, and investment across countries (Catalan, Impavido, \& Musalem, 2000; Chang, Lee, \& Chang, 2013; Ward \& Zurbruegg, 2000).

Levine (1997) highlighted that strong financial systems will positively stimulate the rate of economic growth, which may otherwise be impossible. Furthermore, he added that the development of financial markets is mainly due to market frictions (cost of information and transactions). Put differently, costs of information and transactions give rise to a need for different financial contracts, markets, and financial institutions. Moreover, Jia, Adams, and Buckle (2011) found that companies use insurance to hedge the corporate risk (investment) and this could not be used for speculative purposes like derivatives. Similarly, Ward and Zurburegg (2000) argued that insurance contributes to economic growth by better monitoring from an institutional investor, efficient allocation of resources, and increased opportunities for investment. In addition, Andersson et al. (2010) said that insurance promotes different economic activities i.e. trade, commerce, or investment either by risk sharing or by financial intermediation. Similarly, Bohm and Tumova (2009) identified two types of risk with reference to trade insurance: commercial risk and territorial risk. Commercial risk arises from buyer's financial condition, his ability and willingness to pay. While expropriation, nationalization, moratorium (payment Ban), inability to transfer funds, and war constitutes a territorial risk.

Kugler and Ofoghi (2005) argue that the need for the insurance to boost economic growth was first emphasized at a United Nations on Trade and Development (UNCTAD) conference in 1964. Meanwhile, demand for insurance depends on certain prominent factors highlighted by Browne and Kim (1993), namely, life expectancy, level of education, religion, national income, dependency ratio, expected rate of inflation, social security payments by the government, and cost of insurance (Browne \& Kim, 1993; Beck \& Webb, 2002). Premium charges largely depend on income, the probability of loss, and interest rates. Similarly, Din et al. (2013) argued that as the level of risk (probability of loss) increases the cost of insurance increases as well. Haiss and Sumegi (2008) conducted a study to check separately the relationship between insurance and economic growth for 15 developed and CEE countries (new members of EU) over the period from 1992 to 2005. They found that insurance positively affects economic growth for European countries. However, life insurance plays a vital role in promoting economic growth for developed nations while non-life insurance is more significant in promoting economic growth for less developed EU members. Similarly, Kugler and Ofoghi (2005) concluded that the insurance industry plays a significant positive role in promoting economic growth and there exists a bilateral relationship between economic growth and insurance.

A study carried out by Outreville (1990) utilized cross-sectional analysis on 55 developing countries in order to explore the role of the financial sector, especially insurance, in the economic development of countries. He found that, although financial institutions are playing a vital role in the economic developed of developing countries, policies related to the insurance industry should be given special consideration to boost this industry's contribution in the overall effect of financial institutions on economic growth. Almost a similar study, conducted by Ward and Zurbruegg (2000), explored the role of insurance on economic growth for nine Organizations for Economic Co-operation and Development (OECD) members by implying Granger Causality Test. They, surprisingly, found that insurance's effect on economic growth differs from a different country, therefore, they suggested that role of insurance on economic growth should be studied on per country bases. 
Webb et al. (2002), in addition, took a step ahead from previous researchers and explored the combined and separate role of financial institutions especially banks and insurance companies by using cross-sectional analysis on 55 developed countries. They concluded that banking and insurance have a synergetic effect on economic growth. Adams et al. (2005) also conducted a similar study, which postulates that whether soften credit conditions will boost the economic growth and demand for insurance for Sweden. They utilized the co-integration and Granger causality tests to explore the relationship and the causal effect respectively. They concluded that soften credit conditions will boost the investment behaviour, which corollary increase the demand for insurance.

All the aforementioned studies utilized aggregate data of insurance industry i.e. industry premiums, however, according to Kugler and Ofoghi (2005), using aggregate data might provide spurious results, as the study of Webb et al. (2002) concluded that UK's insurance industry does not contribute into economic growth. Putting it another way, such a huge industry, which constitute almost $7 \%$ of the GDP of UK, has no effect on the economic growth of UK. They suggested that to better capture the relationship, indeed, you need to utilize the disaggregate data of insurance, i.e., life and non-life. They justify their argument by claiming that, as insurance plays the role of financial intermediation, risk transferor, and indemnification of financial losses. The role of financial intermediation is logically associated with life insurance, on the other hand, non-life insurance is considered to play its role in risk transfer. Hence, their effect at a disaggregate level on economic growth will be different. Kugler and Ofoghi (2005), therefore, used disaggregate data of insurance industry of UK to study the relationship between insurance and economic growth by implying a test of co-integration. They concluded, contrary to the Webb et al. (2002), that both life and non-life insurance at disaggregate level positively affects economic growth for the UK. Furthermore, they claimed that there exists a bi-lateral relationship between insurance and economic growth for the UK.

Haiss and Sümegi (2006), similarly, explored the relationship between insurance and economic growth for the twenty-nine European states by using panel data analysis. Their study confirmed and strongly believe that effect of insurance on economic growth differ widely across countries and at the disaggregate level as well. They found life insurance played a vital role for the fifteen developed countries while non-life insurance played its role for the other less developed countries. Arena (2006), in addition, conducted a study on fifty-six countries, taking into account difference in economic levels. The conclusion reinforced the findings of Haiss and Sumegi (2006), non-life insurance has a positive and significant role for all the countries while life insurance played a significant and positive role for the highincome countries as compared to low income.

Curak and Loncar (2008), likewise, investigated the relationship between insurance and economic growth for the forty-three European countries using panel data analysis. Their findings regarding life insurance and economic growth were consistent with the previous studies; however, surprisingly they found an insignificant relationship between non-life insurance and economic growth. Similar, studies conducted by Njegomir and Stojić (2010) concluded a positive relationship between life insurance and economic growth for Yugoslavia. The above literature can be summarized in table for chronologically viewing the wellcited researchers in this field.

Only a few studies explored the role of insurance on economic growth. These studies highlighted insurance, as a risk transferor, indemnification of losses, and financial intermediation, promotes economic growth (Levine, 1997; Catalan, Impavido, \& Musalem, 2000; Ward \& Zurbruegg, 2000; Kugler \& Ofoghi, 2005; Skipper, 2006; Chang, Lee, \& Chang, 2013; Din, Mughal, \& Farooq, 2013). Many authors used the aggregate insurance premiums to measure the insurance activity in an economy, while only Kugler and Ofoghi, (2005); Curak and Loncar (2008) used the life and non-life insurance separately to study their individual effects on economic growth and found inconsistent results. Therefore, based on previous studies, we can hypotheses that:

H1: An aggregate insurance industry positively affects economic growth.

H2: Life insurance positively affects economic growth.

H3: General/non-life insurance positively affects economic growth.

As highlighted above, very few studies are available on the topic of insurance and economic growth at the aggregated and disaggregate level. Although every research claimed, that insurance promotes economic growth via trade, investment, commerce, and financial intermediation. Nevertheless, surprisingly, only one empirical study is available on marine insurance that is co4nsidered to be started $3000 \mathrm{BC}$. Numerous researchers premised that insurance promotes economic growth via risk transfer, indemnification, financial intermediation, trade, commerce etc. Although at numerous places they have mentioned this common opinion, however, not a single researcher except din et al (2013) explored the relationship in this way. Based on the above literature, the following hypotheses are formulated:

H4: Marine insurance positively affects trade. H5: Fire/property insurance positively affects investment. 
Table 1: Key Empirical Papers

\begin{tabular}{|c|c|c|c|}
\hline Author(s) & Method Result & Scope & Result \\
\hline $\begin{array}{l}\text { Outreville } \\
(1990)\end{array}$ & $\begin{array}{l}\text { Cross } \\
\text { Section } \\
\text { Analysis }\end{array}$ & $\begin{array}{l}55 \\
\text { Developing } \\
\text { Countries }\end{array}$ & $\begin{array}{l}\text { Financial sector in developing countries is an important } \\
\text { element of economic development and therefore increase } \\
\text { the supply of the insurance industry argued that policies } \\
\text { should be continued }\end{array}$ \\
\hline $\begin{array}{l}\text { Mohammad } \\
(1998)\end{array}$ & $\begin{array}{l}\text { Regression } \\
\text { Analysis }\end{array}$ & Kuwait & $\begin{array}{l}\text { A one percent increase in per capita income, the insurance } \\
\text { sector increased } 2.9 \text { percent efficiency }\end{array}$ \\
\hline $\begin{array}{l}\text { (Ward \& Zurbruegg, } \\
2000 \text { ) }\end{array}$ & $\begin{array}{l}\text { Granger } \\
\text { Causality } \\
\text { Test }\end{array}$ & $\begin{array}{l}\text { Nine OECD } \\
\text { Countries }\end{array}$ & $\begin{array}{l}\text { They concluded that impact of the insurance industry vary } \\
\text { on economic growth varies based on different levels of } \\
\text { economic development }\end{array}$ \\
\hline $\begin{array}{l}\text { Webb, Grace, \& } \\
\text { Skipper } \\
\text { (2002) }\end{array}$ & \begin{tabular}{|l} 
Cross \\
Section \\
Analysis
\end{tabular} & 55 Countries & $\begin{array}{l}\text { Banking and insurance sector has a positive effect on } \\
\text { economic growth; the result is stronger than the effects } \\
\text { obtained independently from each other. }\end{array}$ \\
\hline $\begin{array}{l}\text { (Kugler \& Ofoghi, } \\
\text { 2005) }\end{array}$ & Co-integration & UK & $\begin{array}{l}\text { The insurance industry plays a significant positive role in } \\
\text { promoting economic growth and there exists a bilateral } \\
\text { relationship between economic growth and insurance }\end{array}$ \\
\hline $\begin{array}{l}\text { Adams et al } \\
(2005)\end{array}$ & $\begin{array}{l}\text { Co-integration } \\
\text { and } \\
\text { Causality } \\
\text { Test }\end{array}$ & Sweden & $\begin{array}{l}\text { Bank credit facility promotes economic growth and demand } \\
\text { for insurance while insurance sector has a positive effect } \\
\text { on economic growth only in boom periods }\end{array}$ \\
\hline $\begin{array}{l}\text { (Haiss \& Sumegi, } \\
\text { 2006) }\end{array}$ & Panel Data Analysis & $\begin{array}{l}29 \text { European } \\
\text { countries }\end{array}$ & $\begin{array}{l}\text { Life insurance significantly affects economic growth for } 15 \\
\text { developed EU. Non-life plays significant role for the less } \\
\text { developed EU members }\end{array}$ \\
\hline (Arena, 2006) & Panel Data & 56 countries & $\begin{array}{l}\text { Both the Life and non-life insurance significantly affects } \\
\text { economic growth. Life insurance affects economic growth } \\
\text { in high-income countries while non-life insurance affects } \\
\text { economic growth in both low and high incomes countries } \\
\text { as well. }\end{array}$ \\
\hline $\begin{array}{l}\text { Vadlamannati } \\
(2008)\end{array}$ & $\begin{array}{l}\text { Co-integration } \\
\text { and } \\
\text { Causality } \\
\text { Test }\end{array}$ & India & $\begin{array}{l}\text { Insurance sector reforms positively affect economic growth } \\
\text { and financial intermediation services are an important part } \\
\text { of the insurance industry }\end{array}$ \\
\hline $\begin{array}{l}\text { (Curak \& Loncar, } \\
\text { 2008) }\end{array}$ & $\begin{array}{l}\text { Panel Data } \\
\text { Analysis }\end{array}$ & $\begin{array}{l}43 \text { European } \\
\text { Countries }\end{array}$ & $\begin{array}{l}\text { A positive relationship between life insurance and economic } \\
\text { growth but found insignificant relation between non-life and } \\
\text { growth }\end{array}$ \\
\hline $\begin{array}{l}\text { (Njegomir \& Stojic, } \\
\text { 2010) }\end{array}$ & Panel Data Analysis & Yugoslavia & $\begin{array}{l}\text { Insurance positively affects economic growth as a risk } \\
\text { transfer, indemnification, and an institutional investor }\end{array}$ \\
\hline $\begin{array}{l}\text { (EGE \& Bahadir, } \\
\text { 2011) }\end{array}$ & $\begin{array}{l}\text { Panel Data } \\
\text { Analysis }\end{array}$ & $\begin{array}{l}\text { OECD } \\
\text { Countries }\end{array}$ & Insurance sector affects economic growth positively. \\
\hline
\end{tabular}


Table 1: Continued

\begin{tabular}{|l|l|l|l|}
\hline Author(s) & \multicolumn{1}{|c|}{ Method Result } & \multicolumn{1}{c|}{ Scope } & \multicolumn{1}{c|}{ Result } \\
\hline $\begin{array}{l}\text { (Horng, Chang, \& } \\
\text { Wu, 2012) }\end{array}$ & $\begin{array}{l}1961-2006 \\
\text { VAR }\end{array}$ & Taiwan & $\begin{array}{l}\text { Financial development promotes economic growth, which } \\
\text { in turn promotes demand for insurance }\end{array}$ \\
\hline $\begin{array}{l}\text { (Din, Mughal, \& } \\
\text { Farooq, 2013) }\end{array}$ & $\begin{array}{l}\text { Time Series/ARDL/ } \\
\text { VECM/Granger } \\
\text { Causality }\end{array}$ & Pakistan & $\begin{array}{l}\text { Marine insurance significantly affects international trade } \\
\text { but the relationship is negative. While non-life insurance } \\
\text { positively affects economic growth }\end{array}$ \\
\hline
\end{tabular}

Source: Din, Abu-Bakar, and Regupathi (2017)

\section{Methodology}

Broadly, data can be categorized into classes, namely, quantitative and qualitative. Quantitative data are used in this study. Based on the extensive literature review, the author comes to know that the majority of studies used the same variables and proxies utilized by Din et al. (2013) in their study, i.e., life and non-life insurance, marine insurance, growth rate of GDP, trade, investment, FDI, inflation, and interest rate.

Statistical Bureau of Pakistan (SBP), the World Bank database, the Insurance Association of Pakistan's industry reports, and the State Bank of Pakistan's publications are used to extract the annual data on the growth rate of gross domestic product, unemployment, inflation rate, trade, investment, and insurance statistics from 1982 to 2018 of Pakistan.

After the UNCTAD report 1964, researchers shifted their focus to explore the role of insurance on economic growth. A few studies used insurance premiums to measure insurance activity, the growth rate of GDP to measure economic growth, and trade openness is used to measure international trade. Most used Ordinary Least Squares (OLS) and Granger Causality test to check the relationship between insurance and economic growth (Outreville, 1990; Mohammad 1998; Ward \& Zurbruegg, 2000; Kugler \& Ofoghi, 2005; Vadlamannati, 2008; Njegomir \& Stojić, 2010; EGE \& Bahadır, 2011; Horng, Chang, \& Wu, 2012; Din, Mughal, \& Farooq, 2013). Therefore, OLS and Granger causality tests check the relationship and direction (uni- or bi-directional) between insurance and economic growth

Literature highlighted that numerous factors, i.e., innovation, R\&D, human capital, investment and savings, trade openness, foreign direct investment, economic policies, political stability, economic policies, and macroeconomic stability of the country, socio-cultural factor (i.e., religion, diversity, trust and so on), geographic importance, and demographic structure (Chen, 2000; Kuznets, 1973; Levine \& Renelt, 1992; North, 1994; Barro, 1996; Petrakos \& Arvanitidis, 2008). Similarly, trade openness is vital for the economic growth of Asian region economies (Chen, 1997). While Baronsztein et al. (1998) claimed that FDI is the most important for economic growth of any country.

$$
\begin{aligned}
\boldsymbol{G}_{G D P=}= & a_{0}+a_{2} \log F D I+a_{3} \log _{-} \text {openness }+a_{4} \log _{-} \text {insurance pre }+U . . \\
\boldsymbol{G}_{G D P=} & a_{0}+a_{2} \text { Log }_{-} F D I+a_{3} \log _{-} \text {openness }+a_{4} \log _{-} \text {Life insurance pre } \\
& +a_{5} \log _{-} \text {Non }- \text { Life insurance pre }+U_{.} .
\end{aligned}
$$

$\mathrm{G}_{\mathrm{GDP}}$ is used to donate growth rate of the gross domestic product, FDI represents a foreign direct investment, openness indicates trade openness (export + imports) $/ \mathrm{G}_{\mathrm{GDP}}$, and insurance pre represents insurance premiums at an aggregate level.

Equation (1) will be used to explore the relationship among economic growth, FDI, an aggregate insurance, and trade openness. Similarly, Equation (2) will be used to explore the relationship of disaggregate insurance, i.e., nonlife and life, foreign direct investment, trade openness, and economic growth.

$$
\begin{aligned}
\log _{\text {Openness }}= & a_{0}+a_{2} \log _{\text {Mar }} \text { Pre }+a_{3} \log _{E x c} \\
& +a_{4} \log _{\text {inf }}+U .
\end{aligned}
$$

Openness is used to donate trade openness, Mar pre represents Marine insurance premiums, Exc indicates exchange rate, and inf represents inflation.

$$
\begin{aligned}
\log _{\text {Investment }}= & a_{0}+a_{2} \log _{\text {pro }} \text { Pre }+a_{3} \log _{E x c} \\
& +a_{4} \log _{\text {inf }}+U .
\end{aligned}
$$


To explore the effects at a disaggregated level of non-life insurance Equation (3) will be used. This will explore the effects of marine premiums, the exchange rate, and inflation on trade openness. Likewise, Equation (4) will be used to explore the relationship between the exchange rate, inflation, and property premiums on investment. All these equations are picked from the Din et al. (2013).

\section{Results and Discussion}

This section will provide the results obtained by carrying out the OLS and Granger Causality models. Before carrying out the OLS, regressions author checked for unit roots for all the variables to avoid the autocorrelation issue. Table 2 the provides the results of the unit root test

Augmented Dickey-Fuller result is used to check the stationary of data, the result shows that all variables are stationary at first difference except log of life insurance premiums (Log life pre). After checking the unit root and making variable stationary, the author runs the Ordinary Least Square (OLS) test, taking into consideration the issues of autocorrelation (see appendix 1.0 Breusch-Godfrey serial correlation test), heteroskedasticity (see appendix 2.0 Breusch-Pagan-Godfrey test), and normality (JarqueBera), to explore the relationship among insurance industry, trade openness, exchange rate on economic growth. Table 3 represents the results obtained from OLS.

\subsection{Equation 1}

OLS (Ordinary Least Square) model is applied to test the relationship among insurance, trade openness, foreign direct investment, and growth of gross domestic product. All variables are stationary at $1^{\text {st }}$ difference.
The results obtained utilizing OLS indicate that collectively these three variables, i.e., insurance, trade openness, and foreign direct investment explain 53\% $\left(R^{2}=0.53\right)$ variation in the dependent variable economic growth. In addition, insurance positively and significantly $(p=0.089$, Coefficient $=-0.96)$ affects the economic growth of Pakistan at 10\% significance level. This finding is consistent with the previous studies done to explore the relationship between insurance and economic growth, which concluded that insurance at an aggregate level plays a positive and significant role in promoting economic growth (Beck \& Webb, 2002; Arena, 2006; Brainard, 2008; Curak \& Loncar, 2008). Similarly, foreign direct investment has a positive significant $(p=0.004$, Coefficient $=1.35)$ effects on economic growth for Pakistan (Borenszteina et al., 1998). However, trade openness affects the economic growth negatively. The result is consistent with numerous studies carried out in the context of Pakistan i.e. (Chaudhary \& Abe, 2000; Sherazi \& Manap, 2004; Afzal, Rehman, \& Rehman, 2009; Din, Mughal, \& Farooq, 2013).

Table 3: Results of regression analysis

\begin{tabular}{|l|c|c|c|}
\hline Particular & Coefficient & T-Value & P-Value \\
\hline Log of Insurance & 0.96 & 1.33 & 0.089 \\
\hline $\begin{array}{l}\text { Log of Foreign } \\
\text { Direct Investment }\end{array}$ & 1.35 & 2.05 & 0.004 \\
\hline $\begin{array}{l}\text { Log of Trade } \\
\text { Openness }\end{array}$ & -1.89 & -3.66 & 0.013 \\
\hline $\mathrm{R}^{2}$ & \multicolumn{3}{|c|}{0.53} \\
\hline
\end{tabular}

Table 2: Dickey-Fuller tests for unit roots (ADF) model

\begin{tabular}{|l|c|c|c|c|c|c|}
\hline Variable & Critical Level & T-Value & 1 $^{\text {st }}$ difference & T-Value & 2 $^{\text {nd }}$ difference & T-Value \\
\hline GGDP & 3.73 & 3.77 & 2.99 & 5.60 & 2.628 & - --- \\
\hline $\begin{array}{l}\text { Log life insurance } \\
\text { pre }\end{array}$ & 3.73 & 0.18 & 2.99 & 1.94 & 2.628 & 5.08 \\
\hline $\begin{array}{l}\text { Log non-life } \\
\text { insurance pre }\end{array}$ & 3.73 & 0.25 & 2.99 & 4.89 & 2.628 & - \\
\hline Log mar pre & 3.73 & 0.43 & 2.99 & 7.29 & 2.628 & - \\
\hline $\begin{array}{l}\text { Log fire insurance } \\
\text { pre }\end{array}$ & 3.73 & 0.39 & 2.99 & 6.55 & 2.628 & - \\
\hline Log inf & 3.73 & 1.86 & 2.99 & 5.24 & 2.628 & - \\
\hline Log exc & 3.73 & 1.43 & 2.99 & 3.90 & 2.628 & -- \\
\hline Log openness & 3.73 & 0.21 & 2.99 & 6.21 & 2.628 & \\
\hline Log FDI & 3.73 & 1.65 & 2.99 & 5.1 & 2.628 & -- \\
\hline
\end{tabular}




\subsection{Equation 2}

OLS is applied to test the relationship between life insurance, non-life insurance, trade openness, foreign direct investment, and growth of the gross domestic product. All variables are $1^{\text {st }}$ difference.

The results obtained utilizing OLS indicate that collectively these four variables i.e. life insurance, non-life insurance, trade openness, and foreign direct investment explain $49 \% \quad\left(R^{2}=0.49\right)$ variation in the dependent variable economic growth. In addition, life insurance is insignificantly $(p=0.239$, Coefficient $=0.96)$ affects the economic growth of Pakistan. Non-life insurance positively and significantly affects the economic growth of Pakistan and the results are in accordance with Arena (2006), who concluded that non-life insurance plays a vital role in developing countries as compared to developed nations. FDI and trade openness both are significant as per the Equation 1 results.

\subsection{Equation 3}

OLS is applied to test the relationship between marine insurance, exchange rate, inflation, and trade openness. All variables are stationary at $1^{\text {st }}$ difference.

The results obtained utilizing OLS indicate that collectively these three variables, i.e., marine insurance, inflation, and the exchange rate explain $\left(R^{2}=0.65 \%\right)$ variation in the dependent variable trade openness with a Durbin-Watson value of 3.18. Further, marine insurance significantly $(p=0.000$, Coefficient $=-0.70)$ affects the trade openness of Pakistan, but the relationship between trade openness and marine insurance is negative as concluded by Din, Mughal, \& Farooq (2013). Similarly, inflation has a negative significant $(p=0.001$, Coefficient $=-1.97)$ effects on trade openness for Pakistan.

The negative sign of marine insurance can be explained with reference to the inefficiency of the production system in Pakistan. These inefficiencies lead to high cost and poor quality, adding additional marine insurance cost in it make Pakistani exporters unable to compete on price in international market. Therefore, Pakistan is facing a consistent trade deficit since its inception (Chishti, 1987). Likewise, volatility in the price level can annihilate the international trade because of exporters/importers loss their confidence regarding the future demands for their product.

\subsection{Equation 4}

Table 6 shows, the results obtained from the execution of OLS Dependent variable is the 1st Difference of trade openness.
Table 4: Results of regression analysis

\begin{tabular}{|l|c|c|c|}
\hline Particular & Coefficient & T-Value & P-Value \\
\hline $\begin{array}{l}\text { Log of life } \\
\text { Insurance }\end{array}$ & 0.96 & 1.33 & 0.239 \\
\hline $\begin{array}{l}\text { Log of Non-Life } \\
\text { Insurance }\end{array}$ & 2.40 & 3.67 & 0.051 \\
\hline $\begin{array}{l}\text { Log of Foreign } \\
\text { Direct Investment }\end{array}$ & 0.99 & 1.98 & 0.038 \\
\hline $\begin{array}{l}\text { Log of Trade } \\
\text { Openness }\end{array}$ & -2.01 & -3.46 & 0.02 \\
\hline$R^{2}$ & \multicolumn{3}{|c|}{0.49} \\
\hline
\end{tabular}

Table 5: Results of regression analysis

\begin{tabular}{|l|c|c|c|}
\hline Variables & Coefficient & T-Value & P-Value \\
\hline $\begin{array}{l}\text { Log of Marine } \\
\text { Insurance }\end{array}$ & -0.70 & -6.20 & 0.000 \\
\hline $\begin{array}{l}\text { Log of Exchange } \\
\text { Rate }\end{array}$ & -1.16 & -1.37 & 0.1819 \\
\hline Log of Inflation & -1.97 & -3.17 & 0.0013 \\
\hline $\mathrm{R}^{2}$ & \multicolumn{3}{|c|}{0.65} \\
\hline
\end{tabular}

Table 6: Results of regression analysis

\begin{tabular}{|l|c|c|c|}
\hline Variable & Coefficient & T-Value & P-Value \\
\hline $\begin{array}{l}\text { Log of Property } \\
\text { Insurance }\end{array}$ & 1.25 & -3.18 & 0.000 \\
\hline $\begin{array}{l}\text { Log of Exchange } \\
\text { Rate }\end{array}$ & -.0 .94 & -1.77 & 0.091 \\
\hline Log of Inflation & 0.87 & -0.84 & 0.340 \\
\hline $\mathrm{R}^{2}$ & \multicolumn{3}{|c|}{0.47} \\
\hline Durbin Watson & \multicolumn{3}{|c|}{2.32} \\
\hline
\end{tabular}

The results obtained utilizing OLS indicate that, collectively, these three variables, i.e., property insurance, inflation, and the exchange rate explain $\left(R^{2}=0.47 \%\right)$ variation in the dependent variable investment with a Durbin-Watson value of 2.32. Further, property insurance significantly $(p=0.000$, Coefficient $=1.25)$ affecting the investment in Pakistan and the relationship between investment and property insurance is positive as concluded by (Ward \& Zurburegg, 2000; Thirlwall, 2003; World Bank Survey, 2009). However, the exchange has negative significant $(p=0.091$, Coefficient $=-0.97)$ effects on investment in Pakistan at $10 \%$ confidence level. 
Table 7: Results of Granger causality test

\begin{tabular}{|c|c|c|}
\hline Variables & $\mathbf{F}$ & $\mathbf{P}$ \\
\hline Marine and Trade & \multirow{3}{*}{$\begin{array}{l}2.87601 \\
0.72502\end{array}$} & \multirow{3}{*}{$\begin{array}{l}0.0798 \\
0.4966\end{array}$} \\
\hline $\begin{array}{l}\text { LOGMARD1 does not Granger } \\
\text { Cause LOGOPEND1 }\end{array}$ & & \\
\hline $\begin{array}{l}\text { LOGOPEND1 does not Granger } \\
\text { Cause LOGMARD1 }\end{array}$ & & \\
\hline $\begin{array}{l}\text { Property insurance and } \\
\text { Investment }\end{array}$ & \multirow{4}{*}{$\begin{array}{l}1.96120 \\
0.43912\end{array}$} & \multirow{4}{*}{$\begin{array}{l}0.0613 \\
0.3435\end{array}$} \\
\hline LOGLIP does not Granger Cause & & \\
\hline LOGGGDP & & \\
\hline $\begin{array}{l}\text { LOGGGDP does not Granger } \\
\text { Cause LOGLIP }\end{array}$ & & \\
\hline $\begin{array}{l}\text { Life Insurance and Economic } \\
\text { Growth }\end{array}$ & \multirow{4}{*}{$\begin{array}{l}2.68903 \\
0.94802\end{array}$} & \multirow{4}{*}{$\begin{array}{l}0.0913 \\
0.4035\end{array}$} \\
\hline \multirow{3}{*}{$\begin{array}{l}\text { LOGLIP does not Granger Cause } \\
\text { LOGGGDP } \\
\text { LOGGGDP does not Granger } \\
\text { Cause LOGLIP }\end{array}$} & & \\
\hline & & \\
\hline & & \\
\hline $\begin{array}{l}\text { Non-life Insurance and } \\
\text { Economic Growth }\end{array}$ & \multirow{3}{*}{$\begin{array}{l}2.18014 \\
2.42344\end{array}$} & \multirow{3}{*}{$\begin{array}{l}0.0328 \\
0.0262\end{array}$} \\
\hline LOGNLIP does not Granger & & \\
\hline $\begin{array}{l}\text { Lause LOGGGDP } \\
\text { CaGGGD does not Granger } \\
\text { Cause LOGNLIP }\end{array}$ & & \\
\hline
\end{tabular}

\subsection{Granger Causality Test}

The results of Granger causality indicates that there exists a uni-directional relationship between marine insurance and trade openness, only marine insurance granger cause the trade openness. Similarly, a uni-directional relationship exists between investment and property insurance, only property insurance granger cause the investment. On the other hand, life insurance granger causes the economic growth, but there is a bi-directional relationship between non-life insurance and economic growth.

\section{Conclusion and Future Research}

Researchers emphasized on the role of banks or stock markets in promoting the economic growth of a country, however, the area of insurance remained ignored until United Nations Conference on Trade and Development in 1964, especially recognized its importance. Moreover, only a handful studies have been carried out on the topic of insurance and it is further in negligible number when it comes to the role of insurance on economic growth of the country.
This study is an attempt to explore the role of the insurance industry and economic growth at an aggregate and disaggregates level from the year 1982 to 2018. Numerous scholars promised that insurance promotes economic growth via trade, commerce, investment, risk hedging, and financial intermediation. Based on the above-mentioned results, the author found that insurance industry at an aggregate level has positive and significant effects on economic growth for the period under study, at 10\% confidence level. While at a disaggregate level only non-life insurance is significantly affecting the economic growth of Pakistan while life insurance does not significantly affect the economic growth. This finding is consistent with the findings of Arena (2006). Furthermore, the author found that non-life insurance at disaggregates behave differently, like marine insurance negatively affecting the trade while property insurance is positively affecting the investment, which is considered vital components of economic growth. Similarly, the author found that an aggregate non-life insurance have a bidirectional relationship with the economic growth, but at the disaggregate level it is uni-directional. In addition, life insurance Granger causes the economic growth.

This article proved that the argument of Kugler and Ofoghi (2005) is valid that using the aggregate data might provide the spurious results. Policy-makers should try to understand the impact of their policies at the disaggregate level rather than viewing the overall affects. This study may provide a roadmap to the future researchers to carry out a comparative analysis of different countries for better generalization of results.

\section{References}

A World Bank Survey. (2009). Trade and Trade Finance Developments in 14 Developing Countries Post September 2008. International Trade Department. Poverty Reduction and Economic Management Network.

Andersson, L. F., Eriksson, L., \& Lindmark, M. (2010). Life insurance and income growth: the case of Sweden 1830-1950. Scandinavian Economic History Review, 58(3), 203-219.

Arena, M. (2006). Does Insurance Market Activity Promote Economic Growth? A Cross-Country Study for Industrialized and Developing Countries. World Bank Policy Research Working Paper 4098. Washington, DC: World Bank.

Barro, R. J. (1996). Determinants of Economic Growth: A CrossCountry Empirical Study. National Bureau of Economic Research, 1-36.

Beck, T., \& Webb, L. (2002). Economic, DemoGraphic, and Institutional Determinants of Life-Insurance Consumption Across Countries. The World Bank Economic Review, 17(1), 51-88.

Borenszteina, E., Gregoriob, J. D., \& Lee, J.-W. (1998). How Does Foreign Direct Investment Affect Economic Growth? Journal of International Economics, 45, 115-135. 
Böhm, A., \& Tůmová, K. (2009). New Challenges of Export Credit Insurance in Current Economic Situation. In: A. Kocourek (Ed.), Liberec Economic Forum (pp. 66-73). Liberec, Czech Republic: Technical University of Liberec.

Brainard, L. (2008, January). What is the Role of Insurance in Economic Development? Zurich Government and Industry Affairs Thought Leadership Series, pp. 1-11.

Browne, M., \& Kim, K. (1993). An International Analysis of Life Insurance Demand. Journal of Risk and Insurance, 60(4), 616634.

Catalan, M., Impavido, G., \& Musalem, A. R. (2000, Aug). Contractual Savings or Stock Markets Development: Which Leads? Retrieved June Sunday, 2019, from http:// elibrary.worldbank.org: http://elibrary.worldbank.org/doi/ pdf/10.1596/1813-9450-2421

Chang, T., Lee, C.-C., \& Chang, C.-H. (2013). Does insurance activity promote economic growth? Further evidence based on bootstrap panel Granger causality test. The European Journal of Finance, 20(12), 1187-1210.

Chaudhary, M. A., \& Abe, K. (2000). Pakistan, Japan and ASEAN Trade Relations \& Economic Development (A Comparative Analysis). Pakistan Economic and Social Review, 38(2), 193214.

Chen, B., \& Feng, Y. (2000). Determinants of Economic Growth in China: Private Enterprise, Education, and Openness. China Economic Review 11, 1-15.

Chen, E. K. (1997). The Total Factor Productivity Debate: Determinants of Economic Growth in East Asia. Asian-Pacific Economic Literature, 11(1), 18-38.

Chishti, M. (1987). Insurance Industry: Policies \& Practice in Pakistan (1st ed.). Karachi, Pakistan: Deens Publications.

Curak, M., \& Loncar, S. (2008). Insurance Development and Economic Growth Nexus. Journal of International Research Publication: Economy \& Business, 3, 97-112.

Dash, S., Pradhan, R. P., Maradana, R. P., Gaurav, K., Zaki, D. B., \& Jayakumar, M. (2018). Insurance market penetration and economic growth in Eurozone countries : Time series evidence on causality. Future Business Journal, 4(1), 50-67.

Din, S. M., Mughal, K. S., \& Farooq, U. (2013). Impact of Cost of Marine and General Insurance on International Trade and Economic Growth of Pakistan. World Applied Sciences Journal, 28(5), 659-671.

Din, S. M. U., Abu-Bakar, A., \& Regupathi, A. (2017). Does insurance promote economic growth: A comparative study of developed and emerging/developing economies. Cogent Economics \& Finance, 5(1), 1390029

Din, S. M. U., Angappan, \& Baker, A. A. (2017). Insurance Effect on Economic Growth- Among Economies in Various Phases of Development. Review of International Business and Strategy, 27(4), 501-519.

Din, S. M. U., Regupathi, A., Abu-Bakar, A., Lim, C. C., \& Ahmed, Z. (2020). Insurance-growth nexus: a comparative analysis with multiple insurance proxies. Economic Research-Ekonomska Istrazivanja, 33(1), 604-622.

Ege, İ., \& Bahadır, T. (2011). The Relationship Between Insurance Sector and Economic Growth: An Econometric Analysis. International Journal of Economic Research, 2(2), 1-9.

Gupta, P., \& Aggarwal, V. (2014). An Analysis of Insurance Sector: Penetration Perspective in India. Indian Institute of Foreign Trade. New Delhi: Centre for WTO Studies (CWS).

Haiss, P. R., \& Sümegi, K. ( 2006). The Relationship between Insurance and Economic Growth - A Theoretical and Empirical Analysis. EcoMod Conference, (pp. 1-38). Hongkong.

Haiss, P., \& Sumegi, K. (2008). The relationship between insurance and economic growth in Europe: a theoretical and empirical analysis. Empirica, 35(4), 405-431.

Hana, L., Lib, D., Moshirianb, F., \& Tian, Y. (2010). Insurance Development and Economic Growth. The Geneva Papers on Risk and Insurance-Issues and Practice, 35, 183-199.

Horng, M.-S., Chang, Y.-W., \& Wu, T.-Y. (2012). Does insurance demand or financial development promote economic growth? Evidence from Taiwan. Applied Economics Letters, 19(2), 105-111.

Insurance Association of Pakistan. (2014, March). IAP. Retrieved June 12, 2014, from http://www.iap.net.pk: http://www.iap.net. $\mathrm{pk} /$ Displaypage.aspx? $\mathrm{ID}=11$

Jia, J. Y., Adams, M., \& Buckle, M. (2011). The strategic use of corporate insurance in China. The European Journal of Finance, 17(8), 675-694.

King, R. O. (2008). Ocean Piracy and its Impact on Insurance. In: Congressional Research Service (pp. 1-11). Washington, DC.

Kugler, M., \& Ofoghi, R. (2005). Does Insurance Promote Economic Growth? Evidence from the UK. In: Money Macro and Finance (MMF) Research Group Conference 2005. Money Macro and Finance Research Group. http://repec.org/mmfc05/paper8.pdf

Kuznets, S. (1973). Modern Economic Growth: Findings and Reflections. The Amercian Economic Review, 63(3), 247-258.

Levine, R. (1997). Financial Development and Economic Growth: Views and Agenda. Journal of Economic Literature, $X X X V$, $688-726$.

Levine, R., \& Renelt, D. (1992). A Sensitivity Analysis of CrossCountry Growth Regressions. The American Economic Review, 82, 942-963.

Marrewijk, c. v. (2002). international trade and the world economy (1st ed.). New York, NY: Oxford University Press.

Ministry of Finance. (2010). The government of Pakistan, Ministry of Finance. Retrieved May 5th, 2012, from http://www.finance. gov.pk/survey/chapter_11/08-Trade\%20and\%20Payments.pdf

Ministry of Finance. (2012). Pakistan Debt Policy Statement 2011-12. The government of Pakistan, Debt Policy Coordination Office.

Njegomir, V., \& Stojić, D. (2010). Does Insurance Promote Economic Growth: The Evidence From Ex-Yugoslavia Region. Ekon. Misao I Praksa DBK. God XiX, 1, 31-48. 
Nguyen, C. H. (2020). The Impact of Foreign Direct Investment, Aid and Exports on Economic Growth in Vietnam. Journal of Asian Finance, Economics and Business, 7(10), 581-589. https://doi.org/10.13106/jafeb.2020.vol7.no10.581

North, D. C. (1994). Economic Performance through Time. Amercian Economic Review, 84(3), 359-368.

Petrakos, G., \& Arvanitidis, P. (2008). Determinants of Economic Growth. Economic Alternatives, 1, 11-30.

Pham, M. H., \& Doan, T. P. L. (2020). The Impact of Financial Inclusion on Financial Stability in Asian Countries. Journal of Asian Finance, Economics and Business, 7(6), 47-59. https:// doi.org/10.13106/jafeb.2020.vol7.no6.047

Ratnawati, K. (2020). The Impact of Financial Inclusion on Economic Growth, Poverty, Income Inequality, and Financial Stability in Asia. Journal of Asian Finance, Economics and Business, 7(10), 73-85. https://doi.org/10.13106/jafeb.2020. vol7.no10.073

Rejda, G. E. (2003). Principles of Risk Management and Insurance ( $8^{\text {th }}$ ed.). Dehli, India: Pearson Education.

Ruiz, J. L. (2018). Financial development, institutional investors, and economic growth. International Review of Economics and Finance, 54, 218-224.

Saunders, A., \& Cornett, M. M. (2008). Financial Institution Management; A Risk Management Approach ( $6^{\text {th }}$ ed.). New York, NY: McGraw-Hill/Irwin.

Securities and Exchange Commission of Pakistan. (2010). How Insurance Works for you. SECP, Insurance Division. Karachi: SECP, Insurance Division.

Security and Exchange Commision of Pakistan. (2000). Insurance Ordinance, 2000. Law Division. Islamabad: SECP.
Skipper, H. D. (2002). Foreign Insurers in Emerging Markets: Issues and Concerns. Washington, DC: International Insurance Foundation.

State Bank of Pakistan. (2003). Review of Insurance Industry. In: Pakistan: Financial Sector Assessment (pp. 95-108).

State Bank of Pakistan. (2010). 6 Performance and Stability Review of the Insurance Sector. Banking, Financial Stability Review. Karachi, Pakistan: SBP.

State Bank of Pakistan. (2008). Banking Sector reform---A Vision and Strategy for the Next 10 Years. Karachi, Pakistan: SBP.

State Bank of Pakistan. (1994). Chapter XIII Import. Karachi, Pakistan: SBP.

State Bank of Pakistan. (2002). State Bank of Pakistan. Retrieved June 18, 2012, from Chapter XIII: www.sbp.org.pk/fe_manual/ chapters/chapter13.htm

Thirlwall, A. P. (2003). Growth \& Development with Special Reference to Developing Economies ( $7^{\text {th }}$ ed.). Kundil, India: Palgrave Macmillan.

Thirlwall, A. P. (2000). Trade, Trade Liberalisation and Economic Growth: Theory and Evidence. Abidjan, Côte d'Ivoire: The African Development Bank.

Ward, D., \& Zurbruegg, R. (2000). Does Insurance Promote Economic Growth? Evidence from OECD Countries. The Journal of Risk and Insurance, 67(4), 489-506.

Wilier, A. H. (1951). The Economic Theory And Insurance. Philadelphia, PA: The S.S. Huebner Foundation for Insurance Education.

Zaidi, S. A. (2000). Issues in Pakistan's economy ( $3^{\text {rd }}$ ed.). Karachi, Pakistan: Ameena Saiyid. 